\title{
Correction of Disorders in Tissue Perfusion, Blood Coagulation and Fibrinolysis with Orbita Apparatus on Terahertz Waves of Cell Metabolites
}

\author{
Vaycheslav Kirichuk, Alexander Tsymbal, Alexey Ivanov, Evgeniy Andronov, \\ Tatyana Kiriyazi, Svetlana Parshina, Natalia Babichenko, Liliana Tokaeva \\ Department of Normal Physiology Named after I.A. Chuevskiy, Saratov State Medical University Named after \\ V.I. Razumovskiy, Saratov City, Russia \\ Email: normalf@yandex.ru
}

Received November 19, 2012; revised December 24, 2012; accepted January 7, 2013

\begin{abstract}
This article contains information on principle of operation, technical parameters and possible application of Orbita apparatus for hemodynamic, fibrinolytic and peripheral perfusion disorders treatment. A single exposure to terahertz waves emitted by Orbita apparatus, corresponding to frequencies of molecular absorption and emission spectra of atmospheric oxygen $(129.0 \mathrm{GHz})$, completely cures coagulant and fibrinolytic disorders of animals with acute immobilization stress. A course of treatment with electromagnetic waves corresponding to frequencies of molecular absorption and emission spectra of nitrogen oxide (150.176 - 150.664) leads to normalization of disrupted peripheral tissue perfusion parameters of animal undergoing treatment and stimulates basal and induced output of nitrogen oxide. This leads to decrease in peripheral vascular resistance to microcirculation and increase in blood flow to microvasculature. Experimental data provided in this article serves as a proof of viability of Orbita apparatus for treatment of coagulant, fibrinolytic and tissue perfusion disorders.
\end{abstract}

Keywords: Orbita Apparatus; Terahertz Waves; Nitrogen Oxide; Atmospheric Oxygen; Stress; Peripheral Perfusion; Coagulation; Fibrinolytic Disorders

\section{Introduction}

Nowadays, developmen $t$ of new drug-free methods of hemodynamic disorder treatment is a subject of intense study. One of such methods is application of low-intensive millimeter and submillimeter radiation [1-4].

In recent years, a new branch of information therapy has emerged - terahertz therapy [5]. Terahertz frequency band makes for an interesting research subject because molecular absorption and emission spectra (MAES) of various cell metabolites (NO, CO, active forms of oxygen etc.) belong to this band [6].

Our experimental studies resulted in creation of Orbita apparatus whose principle of operation is based on application of terahertz electromagnetic waves, corresponding to frequencies of molecular absorption and emission spectra of nitrogen oxide $(150.176-150.664 \mathrm{GHz})$ and atmospheric oxygen $(129.0 \mathrm{GHz})$ [7], emitted by special terahertz wave generators created for the first time.

There is evidence of positive effect of the said frequencies energy deposition on rheological properties of blood and platelet functional activity [8,9], coagulant and fibrinolytic activity [10], blood gas and electrolyte con- centration [11], lipid peroxidation and antioxidative activity [12,13], functional status of thyroid body [14], primary indices of metabolic status [15], concentration of adrenocorticotropic hormone in blood [16], receptor system of formed blood elements [17], state of vascular endothelium [18] and microcirculation [19].

The purpose of this research work is to study the effect of emission produced by Orbita apparatus on peripheral tissue perfusion as well as coagulation and fibrinolytic activities of blood of white rats affected by acute and continuous immobilization stress.

\section{Materials and Methods}

A group of 120 male non-pedigree albino rats with average weight of $180-220 \mathrm{~g}$ was chosen as a test subject. All animals were exposed to similar conditions. An acute and continuous immobilization stress caused by a single or daily 3-hour long immobilization performed to test animals for 5 consecutive days was chosen a model system of coagulation and fibrinolytic activities and microcirculation disorders.

The studied animals were divided into 3 groups of 15 
animal each: 1st group - control group, 2nd groupcomparison group (animals with acute and continuous immobilization stress), 3rd group was comprised of animals exposed to a single terahertz radiation (generated by Orbita apparatus) equal to frequency of atmospheric oxygen $(129.0 \mathrm{GHz})$ for 5, 15 and 30 minutes (respectively) during acute stress and daily terahertz radiation equal to frequencies of nitrogen oxide (150.176 $150.664 \mathrm{GHz}$ ) after every 3-hour long immobilization for 5 consecutive days.

Orbita, a terahertz therapy apparatus, contains two radiation heads: one emitting $129 \mathrm{GHz}$ frequency bands and the other $150 \mathrm{GHz}$ ones. $129 \mathrm{GHz}$ frequency band is one of spectral lines in second zone $(120-132 \mathrm{GHz})$ of molecular absorption spectrum of nitrogen oxide (NO). [6].

The apparatus electrical power is supplied by $(220 \pm$ 22) $\mathrm{V}$ power networks with standard frequency of (50 \pm 0.5) $\mathrm{Hz}$.

Maximal electrical power consumption of this apparatus does not exceed $15 \mathrm{VA}$. The apparatus climate class conforms to boreal climate requirements as prescribed by category 4.2 of GOST (State Standard) No. 15150: working temperature range $-10^{\circ} \mathrm{C}$ to $35^{\circ} \mathrm{C}$, maximal relative humidity $-80 \%$ at $25^{\circ} \mathrm{C}$; ambient pressure range -84 to $106.7 \mathrm{kPa}$ (630 to $800 \mathrm{mmHg}$ ).

Primary technical parameters of this apparatus are as follows:

1) Central frequency of generator with KRPG. 431111.001-01 head: $150.0 \pm 0.75 \mathrm{GHz}$;

2) Radiation power output: $100 \mu \mathrm{W}$;

3) Available time range for therapeutic treatment duration: 1 - 99 minutes;

4) Increment of available time range for therapeutic treatment duration: 1 minute;

5) Maximal electrical power consumption: $15 \mathrm{VA}$;

6) Operating mode setup time: no more than 1 minute;

7) Continuous work time: no less than 8 hours;

8) Expected reliability parameters of apparatus operation (at confidence factor $\mathrm{P}=0.8$ ) shall be as follows:

- Mean time to failure $\left(\mathrm{T}_{0}\right)$ : no less than 400 hours;

- Average useful life $\left(\mathrm{T}_{\text {слл }}\right)$ : no less than 5 years;

- Mean time to recovery $\left(\mathrm{T}_{\mathrm{B}}\right)$ : no more than 3 hours.

Terahertz therapy apparatus consists of MES30A-2PIJ regulated medical type power supply unit $(+9 \mathrm{~V})$ with HO5VV-F networks cable, control and display unit, membrane keyboard and extremely-high frequency (EHF) wave emitter. Control and display unit contains analog signal generator and general purpose control and display element.

Analog signal generator of terahertz therapy apparatus performs functions as follows:

- Generation of continuous voltage $(+5 \mathrm{~V})$ for general purpose control and display element power supply;
- Amplification and stabilization of electric current running through Gunn diode of emitters connected to apparatus;

- Connection/disconnection of EHF wave emitter to/from electric power supply network of generator during reception of control signal from microcontroller of general purpose control and display element;

- Generation of audible signals during reception of control signal from microcontroller of general purpose control and display element;

- ЯКУЛ.467851.016 general purpose control and display element of terahertz therapy apparatus performs functions as follows;

- Reception and processing of signals from membrane keyboard;

- Control over EHF wave emitters power supply and piezoelectric emitter of analog signal generator;

- Provision of information about set operating mode and duration treatment on liquid-crystalline display (LCD).

General purpose control and display element consists of PIC16F876A microcontroller, LCD and keyboard controller and MT-16S2D-2VLB symbol (alphanumeric) LCD produced by МЭЛТ company. Electrical power supply of General purpose control and display element is provided by $\mathrm{L} 7805 \mathrm{CV}$ voltage regulator. The regulator transforms $+9 \mathrm{~V}$ voltage provided by MES30A-2PIJ power supply unit to $+5 \mathrm{~V}$ continuous voltage.

LCD and keyboard controller is built on CE110 microchip. This microchip uses CMDS technology, has a low power consumption rate $(\approx 2 \mathrm{~mA})$ and requires only few external discrete components. For example, this microchip does not require connection to crystal oscillator as its clock frequency is generated by a simple RC-generator. The microchip is connected to electric power supply via CE110 basic connection layout.

PIC16F876A microcontroller produced by MicroChip company is an eight-bit RISC-based processor. This processor is produced by CMOS FLASH/EEPROM method which provides its low power consumption and high speed performance. Memory size of microcontroller is as follows: FLASH memory $-8 \mathrm{~KB}$, EEPROM memory -256 Byte (B), data memory -368 B. Microcontroller can operate in a wide voltage range (from 2 to $5.5 \mathrm{~V}$ ). The microcontroller design allows application of crystal oscillator.

PIC16F876A microcontroller of terahertz therapy apparatus performs functions as follows:

- Reception and transfer of data and control signals to CE110 LCD and keyboard controller via $\mathrm{I}^{2} \mathrm{C}$ interface as regulated by a software program recorded into microcontroller;

- Transmission of $+5 \mathrm{~V}$ voltage pulse to analog signal generator in order to connect/disconnect emitter to/from 
power supply as regulated by a software program recorded into microcontroller;

- Transmission of $+5 \mathrm{~V}$ voltage pulse to analog signal generator in order to switch $3 П-18$ piezoelectric emitter on/off and generate audible signals as regulated by a software program recorded into microcontroller. All software is recorded in controller memory.

The radiation heads consist of brass hull with waveguide channel with $1.6 \times 0.8 \mathrm{~mm}$ section implanted with Gunn diode with in-feed.

Radiation-producing waveguide flange has a thread that can be used to attach a PTFE safety cap transparent for terahertz waves (quenching $-0.3 \pm 0.1 \mathrm{~dB}$ ). Radiation head hull is encased in protective shroud with an identification nameplate containing a six-digit code.

Head power supply is provided by regulated power supply source of control and display unit. Pulse operation of radiation head is provided by switching on impulse power supplied to Gunn diode. In the process of operation the head produces terahertz radiation.

Coagulation and fibrinolytic properties of blood of white affected by acute immobilization stress were studied with a series of tests performed on CGL 2110 "Solar" (Minsk, the Republic of Belarus) turbidimetric coagulation meter using reagents provided by NPO (research and production association) "RENAM" (Moscow, Russia).

Primary characteristics of hemostatic system coagulation include activated partial thromboplastin time (APPT), prothrombin time, international normalized ratio (INR), fibrinogen concentration, thrombin time and factor XIII activity in blood plasma. Anticoagulant blood potency was studied by determination of activity of natural anticoagulants such as antithrombine-III and protein $\mathrm{C}$ contained in blood plasma. Fibrinolytic blood potential was studied with Hageman-dependent and streptokinase-induced euglobulin fibrinolysis by calculating plasminogen reserve index.

Disruption of dermal microvasculature was studied by laser Doppler flowmetry (LDF) on the 6th day since the start of tests with 2 nd version of "ЛАКК-02" blood flow laser analyzer (produced by NPP (research and production enterprise) "Lazma", Russia) and LDF 2.20.0.507 WL software program. In order to immobilize tested animal, it was injected (intramuscularly) with a combination of zoletyl (produced by Virbac Sante Animale, France; doze: $0.05 \mathrm{ml} / \mathrm{kg}$ ) and xylazine (produced by "Interchemie", France; doze: $1 \mathrm{ml} / \mathrm{kg}$ ). Sensor of laser blood flow analyzer is attached to the back surface of right foot with an atraumatic plaster. Standard record time was 7 minutes.

Statistical analysis of obtained data was performed with the help of Statistica 6.0 program. Distribution type hypothesis were checked (Shapiro-Wilk test). A majority of obtained data does not comply with Gaussian distribu- tion law, thus, Mann-Whitney U-test was used to compare data.

\section{Results and Discussion}

Exposure of animals affected with immobilization stress to terahertz radiation equal to frequency of atmospheric oxygen $(129.0 \mathrm{GHz})$ for 5 minutes did not cause significant changes of disrupted coagulant and fibrinolytic parameters as evidenced by a lack of statistically significant discrepancies between characteristic parameters of coagulation cascade and fibrinolysis in comparison to noninvolved animals. However, there is a statistically significant discrepancy between values of primary characteristics of hemostatic system coagulation and fibrinolytic activity of blood in comparison to non-involved animals (Tables 1 and 2).

It should noted that exposure of animals affected with acute immobilization stress to electromagnetic waves from the aforementioned range for 15 minute lead to partial normalization of characteristic parameters of coagulation cascade and fibrinolysis, i.e. APPT and thrombin time were recovered completely and had no statistically significant discrepancies with the same parameters measured for non-involved animals. However, all other hemostatic parameters had statistically significant discrepancies of those of non-involved animals (Tables 1 and 2).

According to test results, perfusion parameter (M) of male rats, affected by continuous stress and exposed to a series of treatment with Orbita apparatus, recovered completely despite having statistically significantly discrepancies from the same parameter measured for animals in control group (Table 3). A statistically significant increase of root mean square deviation of perfusion parameter and variation coefficient is observed for animals of the aforementioned group compared to animals affected with continuous stress and not exposed to terahertz wave radiation (Table 3 ). It should also be noted that the value of root mean square deviation of perfusion parameter and variation coefficient did not reach the control group value which is an evidence of incomplete recovery of micro blood flow modulation and mechanisms of its regulation.

According to results of amplitude-frequency analysis of LDF-charts, a statistically significant increase of amplitudes of vasomotor and endothelial oscillations was observed for male rats, affected by continuous stress and subjected to a series of exposure to electromagnetic waves equal to frequencies of molecular absorption and emission spectra of nitrogen oxide, compared to animals affected with continuous immobilization stress and not exposed to terahertz wave radiation (Table 4). This means that vasodilating activity of endothelium increased (by activation of basal nitrogen oxide production) and 
Table 1. Primary characteristics of hemostatic system coagulation measured after exposure of white rats, affected with experimentally induced stress, to terahertz electromagnetic waves equal to frequencies of molecular absorption and emission spectra of atmospheric oxygen $(129.0 \mathrm{GHz})$ for various time.

\begin{tabular}{|c|c|c|c|c|c|}
\hline \multirow[b]{2}{*}{ Parameter } & \multirow{2}{*}{$\begin{array}{l}\text { Noninvolved animal } \\
\qquad(\mathrm{n}=15)\end{array}$} & \multirow{2}{*}{$\begin{array}{l}\text { Animal under stress } \\
\qquad(\mathrm{n}=15)\end{array}$} & \multicolumn{3}{|c|}{ Exposure to radiation under stress for the time provided below } \\
\hline & & & $\begin{array}{c}5 \text { minutes } \\
(\mathrm{n}=15)\end{array}$ & $\begin{array}{c}15 \text { minutes } \\
(\mathrm{n}=15)\end{array}$ & $\begin{array}{c}30 \text { minutes } \\
(\mathrm{n}=15)\end{array}$ \\
\hline APPT, s & $\begin{array}{c}\mathbf{2 4 . 8} \\
(21.3 ; 26.3)\end{array}$ & $\begin{array}{c}\mathbf{1 9 . 0} \\
(17.9 ; 20.0) \\
\mathrm{P}_{1}<0.05\end{array}$ & $\begin{array}{c}\mathbf{1 9 . 9} \\
(18.1 ; 21.1) \\
\mathrm{P}_{1}<0.05 ; \mathrm{P}_{2}>0.05\end{array}$ & $\begin{array}{c}\mathbf{2 3 . 4} \\
(21.2 ; 25.5) \\
\mathrm{P}_{1}>0.05 ; \mathrm{P}_{2}<0.01 \\
\mathrm{P}_{3}<0.05\end{array}$ & $\begin{array}{c}\mathbf{2 5 . 1} \\
(22.8 ; 27.6) \\
\mathrm{P}_{1}>0.05 ; \mathrm{P}_{2}<0.05 \\
\mathrm{P}_{3}<0.05 ; \mathrm{P}_{4}>0.05\end{array}$ \\
\hline Prothrombin time, $\mathrm{s}$ & $\begin{array}{c}\mathbf{1 9 . 5} \\
(17.3 ; 21.2)\end{array}$ & $\begin{array}{c}\mathbf{1 5 . 0} \\
(14.0 ; 18.0) \\
\mathrm{P}_{1}<0.01\end{array}$ & $\begin{array}{c}\mathbf{1 6 . 1} \\
(15.0 ; 17.8) \\
\mathrm{P}_{1}<0.05 ; \mathrm{P}_{2}>0.05\end{array}$ & $\begin{array}{c}\mathbf{1 7 . 2} \\
(16.2 ; 20.1) \\
\mathrm{P}_{1}<0.05 ; \mathrm{P}_{2}<0.05 \\
\mathrm{P}_{3}>0.05\end{array}$ & $\begin{array}{c}\mathbf{1 8 . 8} \\
(17.5 ; 21.5) \\
\mathrm{P}_{1}>0.05 ; \mathrm{P}_{2}<0.01 \\
\mathrm{P}_{3}<0.05 ; \mathrm{P}_{4}<0.05\end{array}$ \\
\hline $\begin{array}{l}\text { International normalized ratio } \\
\text { (c.u.) }\end{array}$ & $\begin{array}{c}1.22 \\
(0.88 ; 1.44)\end{array}$ & $\begin{array}{c}\mathbf{0 . 8 6} \\
(0.77 ; 1.11) \\
\mathrm{P}_{1}<0.05\end{array}$ & $\begin{array}{c}\mathbf{0 . 9 9} \\
(0.80 ; 1.20) \\
\mathrm{P}_{1}<0.05 ; \mathrm{P}_{2}>0.05\end{array}$ & $\begin{array}{c}\mathbf{1 . 0 1} \\
(0.91 ; 1.44) \\
\mathrm{P}_{1}<0.05 ; \mathrm{P}_{2}<0.01 \\
\mathrm{P}_{3}>0.05\end{array}$ & $\begin{array}{c}\mathbf{1 . 1 1} \\
(1.00 ; 1.35) \\
\mathrm{P}_{1}>0.05 ; \mathrm{P}_{2}<0.05 \\
\mathrm{P}_{3}<0.05 ; \mathrm{P}_{4}<0.01\end{array}$ \\
\hline Thrombin time, s & $\begin{array}{c}22.0 \\
(19.6 ; 23.5)\end{array}$ & $\begin{array}{c}\mathbf{1 5 . 0} \\
(14.2 ; 18.3) \\
\mathrm{P}_{1}<0.01\end{array}$ & $\begin{array}{c}\mathbf{1 6 . 4} \\
(15.0 ; 18.7) \\
\mathrm{P}_{1}<0.05 ; \mathrm{P}_{2}>0.05\end{array}$ & $\begin{array}{c}\mathbf{2 0 . 8} \\
(19.0 ; 23.3) \\
\mathrm{P}_{1}>0.05 ; \mathrm{P}_{2}<0.05 \\
\mathrm{P}_{3}<0.05\end{array}$ & $\begin{array}{c}\mathbf{2 1 . 2} \\
(20.0 ; 24.4) \\
\mathrm{P}_{1}>0.05 ; \mathrm{P}_{2}<0.05 \\
\mathrm{P}_{3}<0.05 ; \mathrm{P}_{4}>0.05\end{array}$ \\
\hline $\begin{array}{l}\text { Fibrinogen concentration, } \\
\mathrm{g} / \mathrm{l}\end{array}$ & $\begin{array}{c}\mathbf{2 . 0} \\
(1.68 ; 2.22)\end{array}$ & $\begin{array}{c}3.7 \\
(1.71 ; 3.75) \\
\mathrm{P}_{1}<0.05\end{array}$ & $\begin{array}{c}3.2 \\
(2.0 ; 3.5) \\
\mathrm{P}_{1}<0.05 ; \mathrm{P}_{2}>0.05\end{array}$ & $\begin{array}{c}2.9 \\
(2.1 ; 3.3) \\
\mathrm{P}_{1}<0.05 ; \mathrm{P}_{2}<0.05 \\
\mathrm{P}_{3}>0.05\end{array}$ & $\begin{array}{c}2.4 \\
(1.75 ; 2.5) \\
\mathrm{P}_{1}>0.05 ; \mathrm{P}_{2}<0.05 \\
\mathrm{P}_{3}<0.05 ; \mathrm{P}_{4}>0.05\end{array}$ \\
\hline $\begin{array}{c}\text { Factor XIII activity in blood } \\
\text { plasma, } \\
\%\end{array}$ & $\begin{array}{c}\mathbf{5 0 . 0} \\
(45.0 ; 70.0)\end{array}$ & $\begin{array}{c}75.0 \\
(60.0 ; 95.0) \\
\mathrm{P}_{1}<0.01\end{array}$ & $\begin{array}{c}\mathbf{7 0 . 0} \\
(57.0 ; 80.0) \\
\mathrm{P}_{1}<0.01 ; \mathrm{P}_{2}>0.05\end{array}$ & $\begin{array}{c}\mathbf{5 7 . 0} \\
(44.0 ; 60.1) \\
\mathrm{P}_{1}<0.05 ; \mathrm{P}_{2}<0.05 \\
\mathrm{P}_{3}<0.05\end{array}$ & $\begin{array}{c}\mathbf{5 4 . 0} \\
(45.2 ; 65.0) \\
\mathrm{P}_{1}>0.05 ; \mathrm{P}_{2}<0.05 \\
\mathrm{P}_{3}<0.01 ; \mathrm{P}_{4}<0.05\end{array}$ \\
\hline
\end{tabular}

Notes: APPT - activated partial thromboplastin time; An average value (median), lower and upper quartiles (25\%, 75\%) from a corresponding number of measurements of every parameter are provided in the table; Discrepancies with $\mathrm{P}<0.05$ were considered statistically significant; $\mathrm{P}_{1}-$ comparison with uninvolved animal group; $\mathrm{P}_{2}$ - comparison with a group of animal with induced immobilization stress; $\mathrm{P}_{3}$ - comparison with a group of animal exposed to radiation under stress for 5 minutes; $\mathrm{P}_{4}$ - comparison with a group of animal exposed to radiation under stress for 15 minutes.

Table 2. Changes of characteristic parameters of anticoagulant and fibrinolytic activities of blood of white rats, affected with experimentally induced stress, after exposure to terahertz electromagnetic waves equal to frequencies of molecular absorption and emission spectra of atmospheric oxygen $(129.0 \mathrm{GHz})$ for various time.

\begin{tabular}{|c|c|c|c|c|c|}
\hline \multirow[b]{2}{*}{ Parameter } & \multirow[b]{2}{*}{$\begin{array}{l}\text { Noninvolved animal } \\
\quad(\mathrm{n}=15)\end{array}$} & \multirow[b]{2}{*}{$\begin{array}{l}\text { Animal under stress } \\
\qquad(\mathrm{n}=15)\end{array}$} & \multicolumn{3}{|c|}{ Exposure to radiation under stress for the time provided below } \\
\hline & & & $\begin{array}{c}5 \text { minutes } \\
(\mathrm{n}=15)\end{array}$ & $\begin{array}{c}5 \text { minutes } \\
(\mathrm{n}=15)\end{array}$ & $\begin{array}{c}5 \text { minutes } \\
(\mathrm{n}=15)\end{array}$ \\
\hline Antithrombin III, s & $\begin{array}{c}\mathbf{3 0 . 0} \\
(25.0 ; 36.0)\end{array}$ & $\begin{array}{c}\mathbf{2 4 . 8} \\
(21.0 ; 30.1) \\
\mathrm{P}_{1}<0.05\end{array}$ & $\begin{array}{c}\mathbf{2 3 . 0} \\
(20.0 ; 27.0) \\
\mathrm{P}_{1}<0.05 ; \mathrm{P}_{2}>0.05\end{array}$ & $\begin{array}{c}\mathbf{2 5 . 0} \\
(23.0 ; 30.0) \\
\mathrm{P}_{1}<0.05 ; \mathrm{P}_{2}>0.05 \\
\mathrm{P}_{3}<0.05\end{array}$ & $\begin{array}{c}\text { 32.0 } \\
(27.0 ; 35.0) \\
\mathrm{P}_{1}>0.05 ; \mathrm{P}_{2}<0.05 \\
\mathrm{P}_{3}<0.05 ; \mathrm{P}_{4}<0.05\end{array}$ \\
\hline Protein $\mathrm{C}$ acitivity, c.u. & $\begin{array}{c}\mathbf{0 . 8 7} \\
(0.60 ; 1.0)\end{array}$ & $\begin{array}{c}\mathbf{0 . 5 4} \\
(0.30 ; 0.61) \\
\mathrm{P}_{1}<0.05\end{array}$ & $\begin{array}{c}\mathbf{0 . 6 1} \\
(0.55 ; 0.77) \\
\mathrm{P}_{1}<0.05 ; \mathrm{P}_{2}>0.05\end{array}$ & $\begin{array}{c}\mathbf{0 . 6 6} \\
(0.60 ; 0.77) \\
\mathrm{P}_{1}<0.05 ; \mathrm{P}_{2}<0.01 \\
\mathrm{P}_{3}>0.05\end{array}$ & $\begin{array}{c}\mathbf{0 . 8 0} \\
(0.77 ; 1.1) \\
\mathrm{P}_{1}>0.05 ; \mathrm{P}_{2}<0.05 \\
\mathrm{P}_{3}<0.05 ; \mathrm{P}_{4}<0.05\end{array}$ \\
\hline $\begin{array}{c}\mathrm{HPa} \text { - kininogenase-dependent } \\
\text { fibrinolysis, min }\end{array}$ & $\begin{array}{c}\mathbf{1 4 . 0} \\
(12.0 ; 16.1)\end{array}$ & $\begin{array}{c}\mathbf{2 4 . 0} \\
(19.0 ; 27.0) \\
\mathrm{P}_{1}<0.01\end{array}$ & $\begin{array}{c}22.4 \\
(20.0 ; 25.0) \\
\mathrm{P}_{1}<0.05 ; \mathrm{P}_{2}>0.05\end{array}$ & $\begin{array}{c}\mathbf{1 8 . 1} \\
(15.0 ; 20.0) \\
\mathrm{P}_{1}<0.05 ; \mathrm{P}_{2}<0.01 \\
\mathrm{P}_{3}<0.05\end{array}$ & $\begin{array}{c}\mathbf{1 5 . 7} \\
(13.0 ; 19.0) \\
\mathrm{P}_{1}>0.05 ; \mathrm{P}_{2}<0.05 \\
\mathrm{P}_{3}<0.05 ; \mathrm{P}_{4}<0.05\end{array}$ \\
\hline $\begin{array}{l}\text { Streptokinase-induced euglobulin } \\
\text { fibrinolysis, } \mathrm{s}\end{array}$ & $\begin{array}{c}\mathbf{1 3 0 . 0} \\
(110.0 ; 160.0)\end{array}$ & $\begin{array}{c}\mathbf{1 8 0 . 0} \\
(160.0 ; 200.0) \\
\mathrm{P}_{1}<0.01\end{array}$ & $\begin{array}{c}\mathbf{1 7 1 . 0} \\
(155.0 ; 190.0) \\
\mathrm{P}_{1}<0.05 ; \mathrm{P}_{2}>0.05\end{array}$ & $\begin{array}{c}\mathbf{1 5 0 . 0} \\
(130.0 ; 170.0) \\
\mathrm{P}_{1}<0.05 ; \mathrm{P}_{2}<0.01 \\
\mathrm{P}_{3}<0.01\end{array}$ & $\begin{array}{c}138.5 \\
(125.0 ; 150.0) \\
\mathrm{P}_{1}>0.05 ; \mathrm{P}_{2}<0.01 \\
\mathrm{P}_{3}<0.01 ; \mathrm{P}_{4}<0.05\end{array}$ \\
\hline Plasminogen reserve index, $\%$ & $\begin{array}{c}\mathbf{7 0 . 1} \\
(61.5 ; 86.6)\end{array}$ & $\begin{array}{c}\mathbf{5 0 . 5} \\
(42.1 ; 60.0) \\
\mathrm{P}_{1}<0.01\end{array}$ & $\begin{array}{c}46.3 \\
(30.3 ; 50.5) \\
\mathrm{P}_{1}<0.01 ; \mathrm{P}_{2}>0.05\end{array}$ & $\begin{array}{c}\mathbf{6 2 . 3} \\
(50.1 ; 70.6) \\
\mathrm{P}_{1}<0.05 ; \mathrm{P}_{2}<0.05 \\
\mathrm{P}_{3}<0.05\end{array}$ & $\begin{array}{c}\mathbf{6 6 . 1} \\
(55.5 ; 80.5) \\
\mathrm{P}_{1}>0.05 ; \mathrm{P}_{2}<0.01 \\
\mathrm{P}_{3}<0.01 ; \mathrm{P}_{4}<0.05\end{array}$ \\
\hline
\end{tabular}

Notes: see Table 1. 
Table 3. Changes of perfusion parameter of animals affected by continuous stress and subjected to a course of treatment with terahertz electromagnetic waves equal to frequencies of molecular absorption and emission spectra of nitrogen oxide (150.176 $150.664 \mathrm{GHz}$ ).

\begin{tabular}{|c|c|c|c|}
\hline Parameter Group & Control group & $\begin{array}{l}\text { Animals affected with continuous } \\
\text { immobilization stress }\end{array}$ & $\begin{array}{c}\text { Animals affected with continuous immobilization stress and } \\
\text { subjected to a course of terahertz waves treatment }\end{array}$ \\
\hline Mean value of perfusion, $\mathrm{pU}$ & $11.28(9.91 ; 13.34)$ & $\begin{array}{c}7.12(6.39 ; 8.63) \\
Z_{1}=3.93 \\
P_{1}=0.000082\end{array}$ & $\begin{array}{c}10.86(9.48 ; 12.47) \\
\mathrm{Z}_{1}=0.55 \\
\mathrm{P}_{1}=0.579100 \\
\mathrm{Z}_{2}=3.22 \\
\mathrm{P}_{2}=0.001260\end{array}$ \\
\hline $\begin{array}{l}\text { Root mean square deviation } \\
\text { of perfusion, } \mathrm{pU}\end{array}$ & $1.02(0.75 ; 1.26)$ & $\begin{array}{c}0.29(0.20 ; 0.33) \\
Z_{1}=4.49 \\
P_{1}=0.000007\end{array}$ & $\begin{array}{c}0.54(0.46 ; 0.67) \\
\mathrm{Z}_{1}=3.18 \\
\mathrm{P}_{1}=0.001425 \\
\mathrm{Z}_{2}=3.91 \\
\mathrm{P}_{2}=0.000093\end{array}$ \\
\hline Variation coefficient, $\%$ & $8.6(7.17 ; 10.87)$ & $\begin{array}{c}3.49(2.80 ; 5.12) \\
\mathrm{Z}_{1}=4.31 \\
\mathrm{P}_{1}=0.000017\end{array}$ & $\begin{array}{c}4.94(4.64 ; 6.05) \\
\mathrm{Z}_{1}=2.93 \\
\mathrm{P}_{1}=0.003283 \\
\mathrm{Z}_{2}=2.14 \\
\mathrm{P}_{2}=0.032388\end{array}$ \\
\hline
\end{tabular}

Notes: An average value (median-Me), lower and upper quartiles $(25 \%, 75 \%)$ from a corresponding number of measurements of every parameter are provided in the table. $Z_{1}, P_{1}$ - comparison with control group; $Z_{2}, P_{2}$ - comparison with a group of animals with continuous stress.

Table 4. Amplitude-frequency characteristics of blood flow oscillations in microvasculature of male rats affected by continuous immobilization stress and subjected to a course of treatment with terahertz electromagnetic waves equal to frequencies of molecular absorption and emission spectra of nitrogen oxide (150.176 - $150.664 \mathrm{GHz})$.

\begin{tabular}{|c|c|c|c|}
\hline Parameter Group & Control group & $\begin{array}{l}\text { Animals affected with continuous } \\
\text { immobilization stress }\end{array}$ & $\begin{array}{c}\text { Animals affected with continuous immobilization stress and } \\
\text { subjected to a course of terahertz waves treatment }\end{array}$ \\
\hline $\begin{array}{l}\text { Maximal amplitude of } \\
\text { endothelial oscillations, } \mathrm{pU}\end{array}$ & $2.08(1.65 ; 2.81)$ & $\begin{array}{c}0.44(0.30 ; 0.59) \\
\mathrm{Z}_{1}=4.49 \\
\mathrm{P}_{1}=0.000007\end{array}$ & $\begin{array}{c}1.20(0.78 ; 1.89) \\
\mathrm{Z}_{1}=2.32 \\
\mathrm{P}_{1}=0.019820 \\
\mathrm{Z}_{2}=3.85 \\
\mathrm{P}_{2}=0.000121\end{array}$ \\
\hline $\begin{array}{l}\text { Maximal amplitude of } \\
\text { respiratory oscillations, } \mathrm{pU}\end{array}$ & $0.34(0.25 ; 0.46)$ & $\begin{array}{c}0.11(0.09 ; 0.20) \\
\mathrm{Z}_{1}=3.38 \\
\mathrm{P}_{1}=0.000710\end{array}$ & $\begin{array}{c}0.21(0.15 ; 0.32) \\
\mathrm{Z}_{1}=1.88 \\
\mathrm{P}_{1}=0.059298 \\
\mathrm{Z}_{2}=2.23 \\
\mathrm{P}_{2}=0.025574\end{array}$ \\
\hline $\begin{array}{l}\text { Maximal amplitude of pulse } \\
\text { oscillations, } \mathrm{pU} \text {. }\end{array}$ & $0.14(0.11 ; 0.29)$ & $\begin{array}{c}0.06(0.04 ; 0.07) \\
\mathrm{Z}_{1}=4.23 \\
\mathrm{P}_{1}=0.000023\end{array}$ & $\begin{array}{c}0.08(0.06 ; 0.11) \\
Z_{1}=2.57 \\
P_{1}=0.009899 \\
Z_{2}=2.29 \\
P_{2}=0.021754\end{array}$ \\
\hline
\end{tabular}

Notes: see Table 3.

peripheral resistance decreased. Amplitudes of respiratory and pulse (cardiac) oscillation also increased (Table 4) which evidences an increment of blood flowing to microvasculature.

Thus, exposure to radiation emitted by Orbita apparatus is an effective method of non-drug treatment of blood perfusion disorders and normalization of coagulant and fibrinolytic acitivites of blood.

\section{REFERENCES}

[1] O. V. Betsky and N. N. Lebedeva, "Application of LowIntensive Millimeter Waves in Biology and Medicine," Biomeditsynksaya Radioelectronika (Biomedical Radioelectronics), No. 8-9, 2007, pp. 6-25.

[2] V. F. Kirichuk, "Physiological Effects of Extremely HighFrequency and Terahertz Electromagnetic Waves: The Discoveries of Saratov Medical Scientists," Biomedit- 
synksaya Radioelectronika (Biomedical Radioelectronics), No. 2-4, 2007, pp. 98-126.

[3] V. F. Kirichuk, "Achievements of Saratov Scientists in Studying the Influence of Extremely High-Frequency and Terahertz Electromagnetic Waves on Humans and Animals," Millimetrovye Volny v Biologii i Meditsyne (Millimeter Waves in Biology and Medicine), No. 3, 2007, pp. 5-71.

[4] V. F. Kirichuk, "Results and Perspectives of Experimental Validation of Application of Terahertz Electromagnetic Waves with Frequencies Equal to Frequencies of Molecular Absorption and Emission Spectra (MAES) of Various Cell Metabolites in Clinical Practice," Millimetrovye Volny v Biologii i Meditsyne (Millimeter Waves in Biology and Medicine), No. 1, 2012, pp. 5-24.

[5] V. F. Kirichuk, T. V. Golovacheva, S. S. Parshina, et al., "Application of NO-Therapy in Clinical Practice," Millimetrovye Volny v Biologii i Meditsyne (Millimeter Waves in Biology and Medicine), No. 1-2, 2009, pp. 5-21.

[6] Y. S. Rothman, J. E. Gordon, A. Barbe, et al., "The HITRAL Molecular Spectroscopic Database 2008," Journal of Quantitative Spectroscopy and Radioactive Transfer, Vol. 110, No. 9-10, 2009, pp. 533-572. doi:10.1016/j.jqsrt.2009.02.013

[7] O. V. Betsky, A. P. Krenitsky, A. V. Mayborodin and V. F. Kirichuk, "Utility Patent: Apparatus for the Treatment of Electromagnetic Waves of Extremely High Frequency," Rospatent No. 50835, 2006.

[8] V. F. Kirichuk, C. V. Sukhova and O. N. Antipova, "Influence of Exposure to Terahertz Electromagnetic Waves with Frequencies Equal to Absorption and Emission Frequencies of Atmospheric Oxygen on Functional Activity of Platelets of Albino Rats with Immobilization Stress," Biomeditsynksaya radioelectronika (Biomedical Radioelectronics), No. 12, 2008, pp. 41-48.

[9] V. F. Kirichuk, A. N. Ivanov and O. N. Antipova, "Electromagnetic Radiation of the Terahertz Range at the Nitric Oxide Frequency in Correction and Prophylaxis of Functional Activity Disorders in Thrombocytes of White Rats under Long-Term Stress," Tsytologiya (Cytology), Vol. 49, No. 6, 2007, pp. 484-490.

[10] V. F. Kirichuk, A. A. Tsymbal, A. P. Krenitsky, et al., "Application of Terahertz Electromagnetic Waves with 129.0 GHz Frequency of Atmospheric Oxygen for Coagulation and Fibrinolytic Disorder Treatment," Biomeditsynksaya Radioelectronika (Biomedical Radioelectronics), No. 9, 2009, pp. 11-16.

[11] A. A. Tsymbal and V. F. Kirichuk, "Changes in Blood Gas and Electrolyte Concentration Caused by Exposure to Terahertz Radiation with Frequencies of 150.176 - 150.64 $\mathrm{GHz}$ during Stress," Patologicheskaya Fiziologiya i EXpermentalnaya Terapiya (Pathologic Physiology and Ex- perimental Therapy), No. 1, 2011, pp. 49-51.

[12] V. F. Kirichuk and A. A. Tsymbal, "Effects of Terahertz Irradiation at Nitric Oxide Frequencies on Intensity of Lipoperoxidation and Antioxidant Properties of the Blood under Stress Conditions," Bulletin of Experimental Biology and Medicine, Vol. 148, No. 2, 2009, pp. 200-203. doi:10.1007/s10517-009-0669-x

[13] V. F. Kirichuk and A. A. Tsymbal, "Application of Terahertz Electromagnetic Waves with Frequencies of Nitrogen Oxide for Correction of Antioxidant Blood Activity and Lipid Peroxidation during Stress," Russian Journal of Physiology Named after N. M. Sechenov, No. 2, 2010, pp. 121-127.

[14] V. F. Kirichuk and A. A. Tsymbal, "Application of Terahertz Electromagnetic Waves with Frequencies of Nitrogen Oxide for Correction of Functional Status of Thyroid Body during Stress," Vestnik RAMN (Bulletin of Russian Academy of Medical Sciences), No. 4, 2010, pp. 37-40.

[15] A. A. Tsymbal, V. F. Kirichuk and A. P. Krenitsky, "Recovery of Primary Indices of Metabolic Status by Exposure to Terahertz Electromagnetic Waves with Frequencies of Nitrogen Oxide (150.176 - $150.64 \mathrm{GHz})$ as a Result of Experiment," Biomeditsynksaya Radioelectronika (Biomedical Radioelectronics), No. 1, 2011, pp. 30-35.

[16] A. A. Tsymbal, V. F. Kirichuk and O. N. Antipova, "Changes of Concentration of Adrenocorticotropic Hormone in Blood of Experimental Animals as a Result of Exposure to Terahertz Electromagnetic Waves with 129.0 $\mathrm{GHz}$ Frequency of Atmospheric Oxygen during Acute and Continuous Stress," Biomeditsynksaya Radioelectronika (Biomedical Radioelectronics), No. 8, 2011, pp. 23-29.

[17] V. F. Kirichuk, A. N. Ivanov and E. V. Andronov, "Influence of Terahertz Electromagnetic Waves with Frequencies of Nitrogen Oxide on Post Stress Disorders of Carbohydrate Component and Activity of Platelet Glycoprotein Receptors," Biomeditsynksaya Radioelectronika (Biomedical Radioelectronics), No. 5, 2010, pp. 39-46.

[18] V. F. Kirichuk, A. N. Ivanov and T. S. Kiriyazi, "Changes in Functional State of Endothelium and Peripheral Perfusion of Albino Rats with Acute Immobilization Stress as a Result of Exposure to Terahertz Electromagnetic Waves with Frequencies of Nitrogen Oxide," Biomeditsynksaya Radioelectronika (Biomedical Radioelectronics), No. 12, 2010, pp. 30-37.

[19] V. F. Kirichuk, A. N. Ivanov and T. S. Kiriyazi, "Correction of Microcirculatory Disturbances with Terahertz Electromagnetic Radiation at Nitric Oxide Frequencies in Albino Rats under Conditions of Acute Stress," Byulleten Experimentalnoi Biologii i Meditsyny (Bulletin of Experimental Biology and Medicine), Vol. 151, No. 3, 2011, pp. 259-262. doi:10.1007/s10517-011-1311-2 